\title{
ANALISIS PENGARUH PENGELUARAN PER KAPITA DENGAN ANGKA HIV DI 34 PROVINSI DI INDONESIA
}

\author{
Fizri Nur Azizah1* and Estro Dariatno Sihaloho2* \\ *Universitas Padjajaran \\ Departmen Ilmu Ekonomi, Fakultas Ekonomi dan Bisnis \\ Sumedang,Indonesia \\ Email: fizri17001@mail.unpad.ac.id
}

\begin{abstract}
Abstrak
Menurut WHO jumlah kematian akibat HIV setiap tahunnya terus meningkat. Saat ini kasus HIV merupakan masalah kesehatan yang banyak dihadapi oleh masyarakat dunia. Menurut WHO, estimasi jumlah penderita HIV di Indonesia disemua umur adalah sekitar 630.000 jiwa. Akibat dari kasus HIV, kekebalan tubuh yang makin menurun akan memudahkan masuknya penyakit kedalam tubuh dan bahkan penyakit ringan pun dapat berubah menjadi penyakit berbahaya. Akses terhadap obat-obatan untuk menyembuhkan HIV tergolong sulit dan mahal harganya. Gangguan kesehatan yang dialami seseorang dapat mempengaruhi produktivitas. Hasil penelitian ini didapatkan bahwa variable yang berpengaruh signifikan terhadap jumlah kasus HIV adalah percapita expenditure, dan PDRB. Sementara Variable Puskesmas dan variable Angka partisipasi murni sekolah dasar tidak berpengaruh secara signifikan. Hasil penelitian ini juga menyebutkan bahwa semakin tinggi pengeluaran perkapita seharusnya jumlah penderita HIV semakin sedikit. Penelitian ini penting untuk sebab kesehatan seseorang akan mempengaruhi produktivitasnya. Oleh karenanya, HIV merupakan hal yang perlu diperhatiakan pertumbuhannya.
\end{abstract}

Kata Kunci: APM SD, HIV, PCE, PDRB, Puskesmas

\begin{abstract}
According to WHO the number of deaths due to HIV each year continues to increase. At present, the case of HIV is a health problem that is often faced by the world community. According to WHO, the estimated number of HIV sufferers in Indonesia at all ages are around 630,000 people? In HIV case, the decreased immune system will cause varied illness, and could cause a minor illness become dangerous diseases. Access to medicines to cure HIV is difficult and expensive. Health problems could affect productivity. The results of this study found that the variables that significantly influence the number of HIV cases are percapita expenditure, and GRDP. Meanwhile the Puskesmas variable and the primary school pure enrollment variable did not significantly influence. The results of this study also mentioned that the higher the per capita expenditure should be, the number of HIV sufferers is getting smaller. This research is important because a person's health will affect his productivity. Therefore, HIV is something that needs to be considered for its growth.
\end{abstract}

Keywords: APM SD, HIV, PCE, PDRB, Puskesmas

\section{Pendahuluan}

HIV kini tidak hanya menyerang orang-orang yang kerap beganti pasangan dalam melakukan hubungan seksual, pengguna narkoba, atau kelompok homosekual, sebab kini HIV telah banyak menyerang wanita-wanita yang hanya memiliki satu pasangan seperti ibu rumah tangga [1]. Yang sangat membahayakan adalah karena ketika seorang ibu terjangkit HIV, maka keturunan yang lahir Akan juga kemungkinan terjangkit HIV. HIV sendiri merupakan virus yang menyerang kekebalan tubuh sehingga akan membuat penderitanya mudah terjangkit penyakit-penyakit. WHO bahkan memperkirakan 
tidak sedikit jiwa yang meninggal akibat HIV di Indonesia yaitu sekitar 39.000 jiwa. Tidak hanya itu fakta yang lebih mengerikan adalah jumlah anak-anak yang terkena HIV adalah sebanyak 14.000 jiwa.

Setiap tahunnya jumlah kematian akibat HIV meningkat, sementara obat untuk menyembuhkan HIV sulit diakses. HIV akan memasuki tahap akhir yang di sebut dengan AIDS. Dampak dari penderita HIV tidak hanya dirasakan oleh penderitanya sendiri tapi juga bisa menular kepada orang lain seperti pasangan, atau bahkan anak yang dikandung (jika penderita merupakan wanita). Tentu hal ini akan menyebabkan externalitas yang berdampak negatif. Banyak hal yang dapat mempengaruhi jumlah penderita HIV sehingga mengkaji mengenai hal-hal yang mempengaruhi penularan HIV merupakan salah satu hal yang baik, dengan tujuan untuk memberikan pengetahuan dan meningkatkan kehati-hatian dalam menjaga kesehatan karena belakangan diketahui bahwa jumlah kasus kematian akibat HIV baru terus meningkat, meskipun kita tidak dapat menghilangkan jumlah penderita HIV secara keseluruhan tapi setidaknya perlu adanya pengurangan jumlah pertambahan kasus baru HIV yaitu dengan dilakukan pencegahan.

Ketika jumlah kasus HIV didunia berkurang, maka hal ini merupakan suatu pencapaian besar. Kasus HIV menjadi hal yang sangat serius, oleh karenanya seluruh dunia dan bakan organisasi dunia sekelas PBB membuat target pengurangan jumlah kasus HIV. Di Indonesia pun pemerintah sudah mulai mengambil langkah untuk mengatasi kasus HIV, baik itu secara pengobatan maupun penyediaan layanan kesehatan dan penyuluhan untuk terus meningkatkan pengetahuan masyarakat terkait bahaya HIV. Keyakinan yang harus ditanamkan adalah bahwa semua orang tidak ingin terjangkit HIV baik terhadap dirinya sendiri, keluarga atau bahkan lingkungan seperti pertemanan. Ketika HIV menyerang tubuh maka penderita akan mudah terkena penyakit yang kemudian akan mengurangi produktivitas atau bahkan sampai kematian. Padahal jika yang terkena HIV adalah orang dewasa maka tanggung jawabnya untuk mencari penghasilan bagi keluarga akan terhambat yang kemudian menyebabkan masalah-masalah lain akan timbul, contohnya kelaparan ataupun kemiskinan.

Berdasarkan data yang bersumber dari BPS, rata-rata jumlah kasus HIV di Indonesia mengalami penurunan jumlah kasus.Pada tahun 2017 jumlah rata-rata kasus HIV di Indonesia adalah sebanyak 1.420,588 kasus, sementara pada tahun 2018 rata-rata kasus HIV adalah sebanyak 1.372,324 kasus. Jumlah rata-rata puskesmas yang dimiliki Indonesia mengalami kenaikan, pada tahu 2017 rata-rata jumlah puskesmas adalah 257,94 sementara pada tahun 2018 rata-rata jumlah puskesmas adalah 262,50. Pengeluaran per kapita (per tahun) juga mengalami kenaikan rata-rata, pada tahun 2017 adalah sebesar Rp 10.274.650 kemudian pada tahun 2018 adalah sebesar Rp 10.622.910. Sementara angka partisipasi murni sekolah dasar mengalami penurunan jumlah rata-rata, yakni pada tahun 2017 sebesar $92,74 \%$ dan pada tahun 2018 sebesar $91,91 \%$. Namun jumlah rata-rata angka partisipasi murni sekolah menengah pertama, dan angka partisipasi murni sekolah menengah atas mengalami kenaikan dari tahun 2017 ke tahun 2018.

Jumlah rata-rata kasus HIV pada tahun 2017 mengalami penurunan pada tahun 2018 maka mengindikasikan bahwa upaya-upaya yang selama ini dilakukan untuk mengurangi jumlah kasus HIV mulai membuahkan hasil, disamping itu jumlah kematian akibat kasus HIV masih menjadi hal yang perlu diperhatikan. Sehingga tujuan dari penelitian ini adalah untuk meningkatkan pemahaman dan kesadaran akan bahaya virus HIV agar semakin banyak upaya yang dapat dilakukan dan semakin besarnya perhatian yang diberikan oleh semua pihak terhadap pertumbuhan kasus HIV, semakin banyak upaya yang dilakukan maka akan semakin besar jumlah penurunan kasus HIV. kualitas kesehatan seseorang akan mempengaruhi produktivitas, oleh sebab itu untuk mencegah penurunan produktivitas akibat gangguan virus HIV, penelitian ini penting untuk dikaji.

\section{Kajian Pustaka}

HIV merupakan virus yang menyerang pasien melalui pelepasan gen asam ribonukleat (RNA), kemudian RNA berubah menjadi virus DNA yang tahap selanjutnya melalui proses inkubasi [2]. Lebih jauh HIV akan berkembang menjadi AIDS (Acquired Immune Deficiency). HIV menyerang sistem kekebalan tubuh sehingga imunnya menurun dan membuat tubuh mudah terkena infeksi dan bahkan mudah terserang penyakit tumor [3]. Resiko HIV dapat meningkat melalui tranfusi darah jika alat yang digunakan tidak steril, ibu hamil terhadap bayi dalam kandungan bahkan jika ibu menyusui terjangkit HIV maka akan meningkatkan resiko terkena HIV pada anak yang menerima ASI, pecandu narkotika, pasangan seks yang berganti-ganti, adanya keluarga yang positif terkena HIV, alat suntik, jarum tato dan tindik [4]. Penyebaran HIV adalah merupakan hal yang harus segera diatasi, apalagi virus HIV dapat menular tentu hal ini akan semakin mengkhawatirkan. Jika virus HIV menyerang perempuan maka 
kehidupan ekonomi keluarga dapat terhambat, keturunan-keturunan yang lahir dari perempuan yang terinfeksi HIV akan berpengaruh pada kesehatannya diusia remaja hingga lansia [5].

Semakin rendah pendidikan seseorang mempengaruhi proporsi kejadian HIV dan AIDS, proporsi kejadian HIV pada kelompok tingkat pendidikan dasar adalah sebesar $64,2 \%$ sementara pada kelompok dengan tingkat pendidikan lanjut adalah sebesar 35,8\%. Hal ini menunjukan bahwa semakin tinggi pendidikan seseorang akan menurunkan kemungkinan resiko terkena virus HIV [6]. Pengetahuan mengenai HIV dan AIDS akan mempengaruhi perilaku individu [7]. Pengetahuan mengenai HIV bisa melalui berbagai media dan salah satunya melalui tulisan, sehingga untuk mendapat informasi tersebut dibutuhkan kemampuan membaca. Pada saat pengetahuan mengenai HIV telah didapatkan maka akan berdampak pada perilaku dalam menyikapi HIV [8].

Jika HIV menyerang masyarakat kurang mampu secara ekonomi, maka akan terjadi keterbatasan dalam mencari akses layanan medis dan harus menunda pemeriksaaan meskipun dirinya sudah jelas merasakan gejala-gejala adanya virus HIV yang mulai menyerang tubuh. Hal ini akan sangat membahayakan bahkan bisa berakibat pada kematian [9].

Pendapatan daerah didapat melalui beberapa sektor yang salah satunya adalah pariwisata, sektor pariwisata ini akan membawa pendatang masuk ke daerah baik sebagai turis maupun sebagai pekerja yang akan membuat haterogenitas dimasyarakat. Dengan adanya pariwisata akan membuat pendapatan daerah meningkat namun disisi lain dengan adanya haterogenitas disuatu masyarakat memungkinkan terjadinya perkembangan HIV dan AIDS lebih luas dimasyarakat [10].

Dengan adanya peningkatan jumlah PDRB maka akan menjadi modal untuk melakukan pembangunan seperti sarana transportasi dan komunikasi yang akan mempermudah mobilitas yang dilakukan oleh masyarakat. Hal ini akan mempengaruhi pola gaya hidup seksual masyarakat sehingga memungkinkan adanya penularan HIV[11].

Peran pusat layanan kesehatan disekitar masyarakat untuk meminimalisir penyebaran HIV dan deteksi dini sangat dibutuhkan contoh kegiatan yang dapat dilakukan adalah dengan edukasi mengenai HIV, yakni dengan pendidikan dan penyuluhan masyarakat mengenai HIV juga sebagai langkah pencegahan penyebaran HIV terutama kepada kelompok yang beresiko tinggi terinfeksi virus HIV [12]. Salah satu penyebab HIV sangat mudah berkembang di negara-negara dunia ke tiga adalah keterbelakangnya pendidikan,ekonomi dan yang paling utama akses untuk kesehatan yang belum memadai atau bahkan belum dapat dijangkau dengan mudah [13].

Dampak dari serangan virus HIV adalah orang tersebut terserang AIDS, AIDS sendiri merupakan sekumpulan penyakit yang menyerang kekebalan tubuh setelah system kekebalannya diserang oleh virus HIV. Individu yang telah terserang HIV/AIDS biasanya akan mengalami gejala panas, diare, batuk, lemas, sesak, dan bahkan menghadapi masalah penyakit berat[14].

\section{Metode Penelitian}

\section{Jenis Penelitian}

Penelitian ini merupakan penelitian kuantitatif yang menggunakan data berupa angka-angka. Penelitian ini juga melakukan analisis ekonometrik untuk melihat bagaimana pengaruh variable independen, yaitu jumlah puskesmas, percapita expenditure, angka partisiasi murni SD dan PDRB terhadap variable dependennya, yaitu jumlah penduduk yang menderita HIV di seluruh provinsi di Indonesia pada tahun 2017 dan 2018.

\section{Jenis dan Sumber Data}

Jenis data yang digunakan dalam penelitian ini merupakan data sekunder yang bersumber dari Badan Pusat Statistik (BPS) dan Departemen Kesehatan (Depkes).

\section{Teknik Pengumpulan Data}

Dalam penelitian ini digunakan teknik pengumpulan data berupa studi dokumentasi yang dilakukan dengan cara mengumpulkan data sekunder, mencatat serta melakukan pengolahan terhadap data-data tersebut.

\section{Teknik Analisis Data}

Data yang digunakan dalam penelitian ini merupakan data panel, yaitu gabungan antara data time series dan data cross-section. Data time series dalam penelitian ini merupakan data yang diamati selama kurun waktu pada tahun 2017 sampai 2018, sementara untuk data cross-section dalam penelitian ini yaitu data untuk variabel jumlah penderita HIV, jumlah puskesmas, percapita expenditure, angka partisiasi murni SD dan 
PDRB pada tahun 2017 dan 2018. Data-data dalam penelitian ini diolah dengan bantuan aplikasi software STATA 14. Persamaan yang digunakan dalam penelitian ini, yaitu :

$$
\begin{aligned}
& \mathbf{Y}_{\text {it }}=\beta_{0}+\beta_{1} \mathbf{X}_{1 i t}+\beta_{2} \mathbf{X}_{2 i t}+\beta_{3} \mathbf{X}_{3 i t}+\beta_{4} \mathbf{X}_{4 i t}+U_{i t} \\
& \text { HIV }_{\text {it }}=\beta_{0}+\beta_{1} \text { Puskesit }+\beta_{2} \text { pce }_{\text {it }}+\beta_{3} \text { apmsd }_{\text {it }}+ \\
& \beta_{4} l_{p d r b}
\end{aligned}
$$

Keterangan:

HIV $_{\text {it }}$ : Jumlah Penderita HIV

Puskes $_{\text {it }} \mathbf{J}$ : Jumlah Puskesmas yang tersedia

Pce $_{i t} \quad$ : Pengeluaran per capita

Apmsd $_{\text {it }}$ : Angka partisipasi murni sekolah dasar

$\operatorname{lpdrb}_{\text {it }} \quad$ : Produk domestic regional bruto atas dasar harga konstan menurut pengeluaran

$\mathrm{U}_{\mathrm{it}} \quad$ : Error Term

\section{Uji Hipotesis}

1) $\quad \boldsymbol{\beta}_{1}$ (Jumlah Puskesmas)

H0 : P-value $=\alpha$, Tidak ada pengaruh yang signifikan antara variabel Independen secara parsial (Jumlah Puskesmas) terhadap variabel dependen (jumlah penderita HIV).

H1 : $P$-value $\neq \alpha$, ada pengaruh yang signifikan antara variabel Independen secara parsial (Jumlah Puskesmas) terhadap variabel dependen (jumlah penderita HIV).

Berdasarkan hasil pengujian $P$-value menggunakan stata 14 variable, jumlah puskesmas terhadap jumlah penderita HIV memperoleh hasil P-value 0.154 dengan $\alpha=10 \%$, maka didapat hasil $P$-value $>\alpha$ $(0.154>0.1)$. Hal ini berarti variable jumlah puskesmas tidak memiliki pengaruh signifikan terhadap jumlah penderita HIV (H0 ditolak)

\section{2) $\quad \boldsymbol{\beta} 3$ (Per Capita Expenditure)}

H0 $: P$-value $=\alpha$, Tidak ada pengaruh yang signifikan antara variabel Independen secara parsial (Per Capita Expenditure) terhadap variabel dependen (jumlah penderita HIV).

H1 : $P$-value $\neq \alpha$, ada pengaruh yang signifikan antara variabel Independen secara parsial (Per Capita Expenditure) terhadap variabel dependen (jumlah penderita HIV).

Berdasarkan hasil pengujian $P$-value menggunakan stata 14 variable Per Capita Expenditure terhadap jumlah penderita HIV memperoleh hasil $P$-value 0.008 dengan $\alpha=5 \%$, maka didapat hasil $P$-value $<\alpha$ $(0.008<0.05)$. Hal ini berarti variable Per Capita Expenditure memiliki pengaruh signifikan terhadap jumlah penderita HIV (H0 diterima)
3) $\quad \boldsymbol{\beta}_{4}$ (Angka Partisipasi Murni Sekolah Dasar)

H0 : $P$-value $=\alpha$, Tidak ada pengaruh yang signifikan antara variabel Independen secara parsial (Angka Partisipasi Murni Sekolah Dasar) terhadap variabel dependen (jumlah penderita HIV).

H1 : P-value $\neq \alpha$, ada pengaruh yang signifikan antara variabel Independen secara parsial (Angka Partisipasi Murni Sekolah Dasar) terhadap variabel dependen (jumlah penderita HIV).

Berdasarkan hasil pengujian $P$-value menggunakan stata 14 variable Angka Partisipasi Murni Sekolah Dasar terhadap jumlah penderita HIV memperoleh hasil $P$-value 0.218 dengan $\alpha=10 \%$, maka didapat hasil $P$-value $>\alpha(0,218>0.05)$. Hal ini berarti

Variable PDRB tidak memiliki pengaruh signifikan terhadap jumlah penderita HIV (H0 ditolak).

4) $\boldsymbol{\beta}_{5}(\mathrm{PDRB})$

H0 : $P$-value $=\alpha$, Tidak ada pengaruh yang signifikan antara variabel Independen secara parsial (PDRB) terhadap variabel dependen (jumlah penderita HIV).

H1 : $P$-value $\neq \alpha$, ada pengaruh yang signifikan antara variabel Independen secara parsial (PDRB) terhadap variabel dependen (jumlah penderita HIV).

Berdasarkan hasil pengujian $P$-value menggunakan stata 14 variable PDRB terhadap jumlah penderita HIV memperoleh hasil $P$-value 0.028 dengan $\alpha=5 \%$, maka didapat hasil $P$-value $>\alpha(0,028>0.05)$. Hal ini berarti variable PDRB memiliki pengaruh signifikan terhadap jumlah penderita HIV (H0 ditolak).

\section{Pembahasan}

Untuk melihat pengaruh pada variable independen (jumlah puskesmas, percapita expenditure, angka partisiasi murni SD dan PDRB) terhadap variable dependen (jumlah penderita HIV) maka dilakukan regresi dengan menggunakan stata 14 , dengan hasil sebagai berikut:

\begin{tabular}{|l|c|}
\hline \multicolumn{2}{|c|}{ (HIV) } \\
\hline VARIABLES & Fixed \\
\hline & \\
\hline Puskes & -7.369 \\
\hline & $(5.045)$ \\
\hline Pce & $-0.390 * * *$ \\
\hline & $(0.137)$ \\
\hline Lapmsd & $-3,847$ \\
\hline & $(3,059)$ \\
\hline Lpdrb & $1,977 * *$ \\
\hline & $(854.4)$ \\
\hline
\end{tabular}




\begin{tabular}{|l|c|}
\hline Constant & $-9,720$ \\
\hline & $(25,634)$ \\
\hline Observations & \\
\hline Number of prov & 68 \\
\hline R-squared & 34 \\
\hline \multicolumn{2}{|c|}{ Standard errors in parentheses } \\
$* * * \mathrm{p}<0.01, * * \mathrm{p}<0.05, * \mathrm{p}<0.1$
\end{tabular}

Hasil diatas menunjukan bahwa model ini mampu menjelaskan variable independen (jumlah puskesmas, percapita expenditure, angka partisiasi murni SD dan PDRB) terhadap variable dependen (jumlah penderita HIV) sebesar $43 \%$ dan sisanya 57\% dijelaskan oleh variable lain diluar model. Pada

hasil regresi tersebut diperoleh hasil 2 variable independen berpengaruh.

Signifikan terhadap jumlah HIV, variable tersebut adalah percapita expenditure, dan PDRB. Dan dua variable independen tidak berpengaruh signifikan yakni variable puskesmas dan angka partisipasi murni sekolah dasar. Tanpa dipengaruhi variable apapun jumlah kasus baru di Indonesia dapat menurun sebanyak 9,720 kasus, Cateris Paribus. Penjabaran mengenai bagaimana setiap variable independen berpengaruh terhadap variable dependen adalah sebagai berikut:

a) Jumlah Puskesmas

Peran adanya puskesmas dimasyarakat sangat membawa dampak baik terhadap kesehatan, puskesmas sudah berperan sebagai pusat layanan informasi kesehatan reproduksi bagi remaja. Hal ini akan berdampak pada tersampaikannya informasi dan terjaganya kesehatan reproduksi remaja [15]. Dengan adanya puskesmas yang memberikan infomasi secara langsung maka tersampaikannya informasi akan diterima dengan sempurna dan akan semakin meningkat pemahaman terhadap bahaya HIV dalam menyalurkan kesehatan selain itu dengan adanya puskesmas maka gejala dini virus HIV akan cepat terdeteksi sehingga penanganan virus HIV bisa dengan cepat dilakukan.

Jika puskesmas dekat dengan masyarakat obat-obatan pun dapat mudah disampaikan kepada masyarakat yang membutuhkan. Sehingga berdasarkan hasil regresi menggunakan stata 14 variable jumlah puskesmas tidak berpengaruh secara signifikan terhadap jumlah penderita HIV, setiap penambahan 1 puskesmas akan mengurangi jumlah penderita HIV sebanyak 7 kasus. Cateris Paribus. dalam penelitian sebelumnya [16] menyebutkan bahwa tidak terdapat hubungan yang berarti antara jarak rumah dengan tempat pelayanan kesehatan jika tidak terdapat kesadaran memeriksa kesehatan pada diri masyarakat.
Namun untuk menanggulangi virus HIV masih dibutuhkan peran puskesmas minimal untuk mendeteksi gejala HIV.

Selain puskesmas yang juga dibutuhkan adalah ketersediaan tenaga medis untuk menangani kesehatan masyarakat dan kemudahan akses terhadap rumah sakit karena fasilitas yang dibutuhkan terkadang tidak tersedia di Puskesmas. Puskesmas merupakan hal yang penting dan harus dimiliki oleh tiap-tiap daerah. Tenaga medis yang dibutuhkan pun harus benar-benar berkualitas salah satunya melalui program internship untuk meningkatkan kemampuan dan pengalaman para tenaga medis yang akan diandalkan untuk menanganis masalah kesehatan khusunya HIV

Menurut data yang dipublikasikan oleh BPS jumlah pemberangkatan tenaga medis untuk internship secara agregat mengalami peningkatan dari tahun 2017 ke tahun 2018 hal ini akan berdampak baik dan tentu dapat berpengaruh pada pelayanan kesehatan masyarakat, tidak hanya tentang virus HIV namun juga penyakit lainnya yang umum terjadi dimasyarakat. Meskipun jumlah tenaga medis banyak, hanya segelintir orang yang mampu merawat ODHA (Orang dengan HIV AIDS) sehingga tenaga kesehatan baik dipuskesmas maupun di rumah sakit harus ditingkatkan pengetahuan dan keterampilannya dalam merawat ODHA dan meminimalisir stigma negatif terhadap ODHA agar pelayanan yang diberikan maksimal [17].

b) Per Capita Expenditure

Setiap kenaikan pendapatan rumah tangga tidak dapat dipastikan bahwa kenaikan jumlah pendapatan tersebut dialokasikan ke sektor pendidikan dan kesehatan, sebab banyak keluarga di negara berkembang justru mengalihkan konsumsinya bukan kepada makanan bergizi namun kepada makanan dengan "kalori nol" seperti permen, soda dan makanan lain yang dianggap sebagai makanan mewah. Namun berbeda dengan situasi dimana konsumsi individu dialokasikan untuk pendidikan dan kesehatan maka akan memberikan pengembalian yang luar biasa besarnya seperti meningkatnya produktivitas [18]. Artinya semakin besar pengeluaran rumah tangga jika dialokasikan kepada sektor kesehatan maka kualitas kesehatan dari anggota rumah tangga akan semakin terjaga, terutama untuk menjaga diri dari HIV tidak dapat dianggap enteng dan perawatan terhadap pasien yang telah terinfeksi HIV juga bukan merupakan hal yang mudah dan murah harganya.

Hasil regresi menggunakan stata 14 menunjukan setiap 100\% kenaikan Per Capita Expenditure akan berdampak pada penurunan jumlah kasus HIV 
sebanyak 39 kasus, cateris paribus. Melihat hal ini tentu pengeluaran per capita ke sektor kesehatan adalah hal yang penting, alangkah lebih baiknya konsumsi dilakukan kepada hal-hal yang dapat meningkatkan kesehatan dibandingkan ke sektor-sektor konsumsi yang kurang membawa manfaat.

c) Angka Partisipasi Murni Sekolah Dasar

Angka melek huruf merupakan cerminan dari kualitas pendidikan masyarakat, semakin besar jumlah masyarakat yang melek huruf maka semakin mudah informasi tersampaikan, bahkan dengan kemampuan membaca seseorang dapat mengetahui isi kandungan obat-obatan karena dapat membaca komposisi obat yang tercantum dalam kemasan. Kemampuan membaca tersebut didapat melalui pendidikan ditingkat sekolah dasar, sehingga pendidikan dasar merupakan hal yang penting untuk membuat masyarakat terbebas dari buta huruf.

Dengan menggunakan stata 14 hasil regresi menunjukan bahwa variable angka partisipasi murni sekolah dasar merupakan variable yang tidak bepengaruh signifikan terhadap jumlah kasus baru HIV, hubungan antara variable angka partisipasi sekolah dasar terhadap variable kasus HIV adalah negatif sehingga setiap kenaikan jumlah orang yang bersekolah ditingkat dasar sebanyak $1 \%$ akan mengurangi jumlah kasus baru HIV sebanyak 3-4 kasus, Cateris Paribus. Namun apabila dilihat dari sudut pandang pendidikan yang diasumsikan bahwa angka partisipasi murni merupakan variable mendeskripsikan pendidikan di Indonesia maka hasil yang didapat adalah sebagai berikut:

\begin{tabular}{|c|c|}
\hline & (2) \\
\hline VARIABLES & Hiv \\
\hline \multirow[t]{2}{*}{ Lapmsd } & $-7,167 * * *$ \\
\hline & $(2,448)$ \\
\hline \multirow[t]{2}{*}{ Lapmsmp } & $-4,615 * * *$ \\
\hline & $(1,604)$ \\
\hline \multirow[t]{2}{*}{ Lapmsma } & -385.0 \\
\hline & $(723.5)$ \\
\hline \multirow[t]{2}{*}{ Constant } & $55,312 * * *$ \\
\hline & $(15,554)$ \\
\hline Observations & 68 \\
\hline Number of prov & 34 \\
\hline R-squared & 0.291 \\
\hline
\end{tabular}

Hasil regresi diatas menunjukan bahwa variable angka partisipasi murni SD,dan SMP adalah variable yang berpengaruh signifikan terhadap kasus baru HIV sementara variable angka partisipasi murni SMA tidak berpengaruh signifikan. Melihat hasil regresi ini dapat disimpulkan bahwa pendidikan dasar merupakan hal yang penting untuk membantu mengurangi kasus baru HIV apalagi kini kebanyakan informasi diakses melalui internet yang berupa tulisan, selain itu untuk menyampaikan informasi yang dilakukan melalui penyuluhan seharusnya pemaparan yang diberikan dicatatat agar dapat dipelajari dan diingat. Jika kebanyakan orang tidak dapat membaca maka akan tejadi kesulitan akses penyampaian informasi.

Bahkan dalam penelitian yang dilakukan sebelumnya [19] menyebutkan bahwa tidak hanya pendidikan yang berpengaruh terhadap HIV, HIV pun berdampak besar terhadap pendidikan atau lebih spesifik angka partisipasi sekolah. Umumnya rumah tangga $\mathrm{ODH}$ memiliki kesulitan akses untuk mendapat pendidikan lebih tinggi, hal ini diakibatkan oleh besarnya biaya yang ditanggung untuk kebutuhan dasar seperti kesehatan dan juga kemungkinan anak tejangkit virus HIV akan menghambat proses belajar. Pemaparan tersebut menunjukan adanya hubungan timbal balik antara HIV dengan pendidikan, aspek pendidikan yang dimaksud yang paling utama adalah kemapuan membaca sebab membaca merupakan gerbang dari segala macam informasi

\section{d) PDRB}

PDRB atau produk domestic regional bruto merupakan barang dan jasa yang dihasilkan oleh penduduk daerah. Ketika jumlah PDRB tinggi menunjukan bahwa pendapatan yang diterima daerah tinggi. Hal ini akan mempengaruhi kemampuan daerah dalam memenuhi kebutuhannya. Sebab PDRB merupakan salah satu indikator untuk melihat potensi daerah.

Salah satu penyumbang pendapatan daerah adalah melalui pariwisata, namun dengan pariwisata yang berkembang dimasyarakat akan membuat tingginya mobilitas masyarakat yang kemudian akan mendorong terjadinya haterogenitas di masyarakat, hal ini memungkinkan adanya penyebaran HIV melalui wisatawan ataupun masyarakat luar daerah. Penyebaran dapat dilakukan melalui penggunaan narkoba melalui jarum suntik yang dilakukan bersama-sama, atau bahkan perilaku sex bebas yang dilakukan tanpa pengaman.

Hasil dari regresi stata 14 peningkatan PDRB sebanyak $1 \%$ akan meningkatkan jumlah kasus baru HIV sebanyak 1.977 kasus, cateris paribus. Dalam penelitian sebelumnya [11] menyebutkan bahwa mobilitas penduduk akan meningkatkan jumlah kasus HIV (berhubungan positif). Mobilitas yang dimaksud 
tidak hanya mobilitas yang dilakukan oleh penduduk daerah (internal) ke daerah lain (eksternal) tapi juga mobilitas yang dilakukan penduduk daerah lain (eksternal) yang masuk ke daerah kita (internal). Mobilitas penduduk yang tinggi jika diasumsikan adalah untuk bekerja maka itu menandakan bahwa dampak dari mobilitas penduduk adalah peningkatan PDRB.

\section{Human Imunodeficiency Virusess}

Cara kerja virus HIV adalah dengan menyerang system imun tubuh, virus HIV dapat tumbuh dan berkembang di dalam darah,cairan sperma, cairan vagina, dan ASI. Ketika virus HIV hidup dalam tubuh seseorang maka penyakit yang tidak berbahaya pun akan menjadi penyakit berbahaya akibat dari rusaknya system kekebalan tubuh. Virus HIV akan dengan mudah menular kepada orang lain baik melalui hubungan seksual maupun melalui air susu ibu, itulah mengapa ibu yang menderita HIV akan sangat membahayakan keluarganya (terutama ibu hamil dan ibu menyusui) karena bisa jadi virus tersebut menjadi virus yang diturunkan terhadap anaknya.

Kini tidak hanya pekerja seks komersial maupun pengguna obat-obatan terlarang yang dapat dengan mudah mejadi korban penyebaran virus HIV, ibu rumah tangga pun dapat terserang. Sejalan dengan hasil penelitian yang dilakukan oleh Dalimoenthe, hasil regresi yang telah dilakukan melibatkan angka melek aksara, dan gini ratio terhadap kasus HIV adalah benar adanya. Angka melek aksara memiliki hubungan negatif, dalam penelitian ini peneliti memandang angka melek aksara sebagai indikator pendidikan, ketika kemampuan membaca dimasyarakat baik maka menandakan pendidikan yang dimiliki masyarakat pun baik. Semakin tinggi tingkat pendidikan seseorang akan meningkatkan pemahaman seseorang terhadap hal-hal yang wajib diketahui atau dengan kata lain aka memudahkan penerimaan informasi baru. Pada gini ratio, ketimpangan yang terjadi akan memungkinkan adanya penyebaran kasus HIV akibat keadaan ekonomi, namun jika ketimpangan terjadi maka orang dengan penghasilan rendah akan kesulitan akses mendapat penanganan virus HIV yang berakibat pada kematian itulah kenapa gini ratio berpengaruh negatif terhadap kasus HIV. Dengan ketimpangan yang terjadi kasus HIV memang dapat berkurang, namun kematian akibat HIV akan bertambah, cateris paribus.

Pada laporan yang dilakukan WHO mengenai kasus HIV di Indonesia menyebutkan bahwa estimasi jumlah penduduk Indonesia yang meninggal akibat AIDS terus meningkat sejak tahun 2010 hingga tahun 2017, fakta diatas sangat memprihatinkan. Bahkan
WHO memprediksi bahwa negara-negara yang terserang virus HIV kebanyakan merupakan negara berkembang. HIV kebanyakan terjadi di negara afrika, dan penduduk terbanyak kedua yang hidup dalam HIV adalah di Asia. Hal ini tentu menjadi hal yang tidak dapat diabaikan [20].

Penularan kasus HIV juga bisa terjadi pada individu dengan orientasi homoseksual dan atau pun hateroseksual, alasan mengenai kerentanan gay terserang virus HIV adalah karena aktivitas seksual yang dilakukan adalah berupa anal dan oral seks, yang memungkinkan adanya kemudahan dalam penyebaran virus HIV [21]. Seseorang yang menerima dirinya sebagai seorang gay umumnya lebih beresiko terinfeksi virus HIV, ketika semakin seringnya gay melakukan hubungan seksual anal maka penyebaran virus HIV akan semakin mudah tersebar karena anal memiliki lapisan kulit yang tipis, mudah terluka dan bahkan rentan tergores.

Fakta yang selanjutnya harus menjadi perhatian mengenai orang-orang yang rentan terserang HIV adalah waria, umumnya waria bekerja sebagai pekerja seks. Tak jauh berbeda dengan gay, para waria yang bekerja sebagai pekerja seks akan melakukan hubungan intim melalui anal dan oral bahkan AMFAR (Yayasan Riset AID Amerika) menyebutkan bahwa waria memiliki 19 kali lebih tinggi resiko terkena virus HIV[22].

Untuk mengenali gejala serangan virus HIV tidak dapat disama ratakan, sebab ada kelompok orang yang tidak merasakan apa-apa (merasa sehat) ada juga orang yang ketika darahnya dicek mendapat hasil negatif padahal sudah terinfeksi virus HIV. Hal ini bisa saja terjadi sebab mungkin tubuh masih dalam fase pembentukan antybody periode dimana diperlukan waktu hingga 15 hari untuk menentukan bahwa virus HIV sudah benar-benar masuk ke tubuh. Waktu paling lama terdiagnosis infeksi HIV dapat mencapai 5 tahun. Namun ada juga kelompok yang merasakan tanda-tanda adanya virus HIV dalam tubuh, tanda-tanda ringan yang dirasakan adalah berupa berat badan yang menurun drastis, sering demam, keletihan yang berkepanjangan, diare tanpa sebab, dan bahkan sariawan dan panas dalam yang sukar untuk sembuh. Sementara gejala beratnya adalah berupa sesak, radang paru-paru, batuk tanpa sebab (berupa batuk kering), bercak berwarna merah ungu pada kulit tubuh bawah, bercak-bercak putih pada mulut, gangguan syaraf otot, gangguan ingatan dan bahkan perubahan kepribadian [23]. Meskipun seorang penderita HIV belum terdeteksi terkena virus HIV namun jika benar adanya sudah terinfeksi virus HIV maka penyebaran virus HIV kepada orang lain tetap dapat terjadi. Untuk mendiagnosis adanya virus HIV dalam tubuh tidak 
dapat dilakukan dengan hanya menerka-nerka harus dilakukan uji lab atau test keseluruhan melalui test darah untuk membuktikan kebenaran ada tidaknya virus HIV dalam tubuh.

Namun yang tidak kalah pentingnya adalah dukungan moril untuk ODHA (Orang Dengan HIV AIDS), sebab ketika didiagnosa terkena penyakit HIV tentu tidak ada seorang pun yang senang. Bahkan terkadang berimbas pada kesehatan mental yang parahnya membuat tidak ada lagi semangat melanjutkan hidup. Sikap orang lain yang sehat dari virus HIV terkadang dapat melukai ODHA contohnya adalah perilaku tidak mau bersentuhan dengan ODHA akan membuat semakin terlukanya batin ODHA. Padahal perlu diingat penularan virus HIV tidak melalui sentuhan, banyak orang yang menderita HIV/AIDS merasa terkucilkan dimasyarakat yang membuat semakin kecilnya semangat untuk sembuh atau untuk melakukan pemeriksaan dan pengobatan. Jika semangat hidup dari ODHA terus menurun maka usaha untuk menjaga tubuh tetap hidup akan semakin kecil yang bisa membuat pemikiran untuk memilih tidak melakukan perawatan sebab sudah putus asa.Upaya yang dapat dilakukan untuk tidak terkena virus HIV adalah bukan dengan membatasi interaksi dengan ODHA, namun dengan menjaga organ reproduksi tetap sehat misalkan dengan tidak berhubungan seksual dengan sembarang orang, sebab individu yang memiliki satu pasangan untuk berhubungan seksual pun masih memiliki kemungkinan untuk terserang virus HIV apalagi mereka yang bergonta ganti pasangan. Upaya selanjutnya adalah dengan tidak menggunakan narkotika dan obat-obatan terlarang, karena penyebaran virus HIV dapat terjadi melalui jarum suntik yang dilakukan bersama. Dan menanamkan kesadaran untuk memeriksakan diri secara berkala pun perlu dilakukan untuk mendeteksi secara dini serangan virus HIV. Kesehatan merupakan hal yang paling mahal dan merupakan anugrah Tuhan yang tidak terhitung nilainya, dan tugas manusia adalah menjaganya agar tetap dalam keadaan sehat. Memperhatikan asupan gizi dan makanan yang masuk ketubuh dan rutin berolahraga merupakan salah satu bentuk cinta terhadap diri sendiri dan wujud terimakasih kepada Tuhan (melalui menjaga kesehatan).

Kasus HIV harus menjadi perhatian besar agar dapat mengurangi jumlah orang yang positif terinfeksi HIV, disamping itu jumlah kematian akibat HIV/AIDS juga tidak kalah penting untuk ditangani. Keterlibatan peran pemerintah sangat diperlukan seperti penyediaan layanan kesehatan, dan penyediaan teaga medis yang mampu menangani ODHA (sebab tidak semua tenaga medis mampu menangani ODHA) kampanye bahaya HIV dan pentingnya hidup sehat, hal lain yang tidak kalah pentingnya adalah perlunya peran pemerintah dalam mengawasi dan menindak lanjut penggunaan narkotika

Sementara langkah yang sangat diharapkan dapat dilakuka oleh masing-masing inividu adalah dengan menjaga pola hidup sehat, tidak bergonta ganti pasangan dalam berhubungan seksual, menjaga kebersihan dan kesehatan organ reproduksi. Namun, sebagai orang yang tidak terserang virus HIV pun setiap individu perlu memberikan dukungan moral untuk ODHA dan tidak mendiskriminasi ODHA. Sebagai sesame manusia ODHA berhak mendapatkan perlakuan yang baik seperti halnya orang-orang sehat.

\section{Kesimpulan}

Berdasarkan hasil penelitian ini dapat disimpulkan hubungan antara variable independen terhadap variable dependen dalam model adalah sebagai berikut:

a. Jumlah puskesmas tidak perpengaruh signifikan terhadap jumlah kasus HIV di Indonesia, namun jumlah puskesmas memiliki hubungan negatif dengan jumlah kasus HIV.

b. Pengeluaran per capita masyarakat Indonesia berpengaruh signifikan terhadap jumlah kasus HIV,

c. hubungan antara jumlah pengeluaran per capita masyarakat dengan kasus HIV adalah negative

d. Angka partisipasi murni sekolah dasar tidak berpengaruh signifikan terhadap jumlah kasus HIV, namun memiliki hubungan yang negative

e. Pendapatan domestik regional bruto berpengaruh signifikan terhadap jumlah kasus HIV, dan memiliki hubungan positif

\section{Saran}

Melihat data jumlah kematian akibat HIV yang terus meningkat, peneliti berharap agar semakin banyaknya usaha yang dilakukan semua pihak untuk mengurangi kasus HIV terutama peran pemerintah untuk terus mengedukasi masyarakat terkait bahaya HIV/AIDS.

\section{Daftar Pustaka}

[1] Pati, K., \& Tengah, J. (2013). Kerentanan Perempuan Terhadap Penularan HIV \& AIDS : Palastren, 6(1), 185-200.

[2] Kumalasari, Ii. Y. (2013). Perilaku Berisiko Penyebab Human Immunodefieciency Virus (HIV) Positif ( Studi Kasus di Rumah Damai 
Kelurahan Cepoko Kecamatan Gunungpati Kota Semarang ).

[3] DEPKES RI. (2008). Dirjen Pengendalian Penyakit dan Penyehatan Lingkungan.

[4] Nyoman S. (1990). Epidemiologi AIDS Standarisasi Diagnostik dan Penatalaksanaan beberapa penyakit menular Seksual.

[5] Dewi, D. M. S. K., Wulandari, L. P. L., \& Karmaya, I. N. M. (2013). Kerentanan perempuan terhadap penularan IMS dan HIV: gambaran perilaku seksual berisiko di Kota Denpasar. Public Health and Preventive Medicine Archive, 1(1), 13.

https://doi.org/10.15562/phpma.v1i1.152

[6] Susilowati, T. (2011). Faktor - faktor risiko yang berpengaruh terhadap kejadian HIV dan AIDS di Semarang dan sekitarnya. Jurnal Komunikasi Kesehatan, 2(01), 1-16. https://doi.org/10.1021/bc060129j

[7] Hidayat Oryza, G. srirum. (n.d.). Tingkat Pengetahuan Mahasiswa Universitas Gadjah Mada Tentang Bahaya Penyakit Aids, 6(2), 103.

[8] Oktarina, Fachrudin, H., \& Budisuari, M. (2013). Hubungan Antara Karakteristik Responden, Keadaan Wilayah dengan Pengetahuan, Sikap Terhadap HIV/AIDS pada Masyarakat Indonesia. Buletin Penelitian Sistem Kesehatan, 124(4), 362-369.

https://doi.org/10.22435/BPSK.V12I4.2742

[9] Kumalasari, Ii. Y. (2013). Perilaku Berisiko Penyebab Human Immunodefieciency Virus (HIV) Positif ( Studi Kasus di Rumah Damai Kelurahan Cepoko Kecamatan Gunungpati Kota Semaran ).

[10] Divayana, D. G. H. (2015). Evaluasi Program Penanggulangan HIV / AIDS Dengan Model CIPP Berbantuan Komputer. Konferensi Nasional Sistem \& Informatika, 9-10.

[11] Dewi Rokhmah. (2014). Implikasi Mobilitas Penduduk Dan Gaya Hidup Seksual Terhadap PENULARAN HIV/AIDS.

[12] Budisuari, M. A. (2002). Hubungan Antara Karakteristik Responden, Keadaan Wilayah Dengan Pengetahuan, Sikap Terhadap Hiv / Aids Pada Masyarakat Indonesia.

[13] Rahakbauw, N. (2016). Dukungan Keluarga Terhadap Kelangsungan Hidup Odha (Orang
Dengan Hiv/Aids) Oleh Nancy Rahakbauw*, 3(2). Retrieved from stisipwiduri.ac.id

[14] Astuti, A., \& Budiyani, K. (2010). Hubungan antara dukungan sosial yang diterima dengan kebermaknaan hidup pada ODHA (orang dengan HIV/AIDS). Insight, 1-10.

[15] Paramita, A., Widjiartini, \& Soeparmanto, P. (2006). Pelayanan Kesehatan Reproduksi Remaja Oleh Puskesmas Yang Dl Wilayah Kerjanyaterdapat Lokasi Prostltusl (Studi di Kota Malang dan Kabupaten Tulungagung).

[16] Burhan, R. (2015). Pemanfaatan Pelayanan Kesehatan oleh Perempuan Terinfeksi HIV / AIDS Health Service Utilization in Women Living with HIV / AIDS, (03), 33-38.

[17] Waluyo, A., Nova, P. A., \& Edison, C. (2011). Perilaku Perawat Terhadap Orang Dengan Hiv / Aids. Jurnal Keperawatan Indonesia, 14(2), 127-132.

[18] P.Todaro, M. (2006). Economic Development (09 ed.). Jakarta: ERLANGGA.

[19] Sutrisna, A. (2009). Child Poverty and Social Protection Conference Dampak HIV Pada Pendidikan Anak di Indonesia, 1-24. Retrieved from http://www.smeru.or.id/cpsp/Paper, Abstact, CV/0103_Aang-paper.pdf

[20] WHO. (2017). Number of people (all ages) living with HIV Estimates by country.

[21] Abdul Aziz Azari. (2018). Self-Label Pada Remaja Gay Dengan Perilaku Seksual Beresiko Terhadap Penularan IMS dan HIV-AIDS.

[22] GUTERRES, M. A. D. O. (2015). Beberapa Faktor Risiko Yang Berpengaruh Terhadap Kejadian Hiv/Aids Pada Laki-Laki Umur 25-44 Tahun (Studi Kasus di KOta Dili, Timor Leste) (Doctoral dissertation, Diponegoro University), 1-14.

[23] Hamidy, M. I. M. (n.d.). Ancaman Virus Hiv / Aids Dan Upaya Pencegahannya ( Dalam Perspektif Sosiologis dan Agama ), V(1), 60-77 